Proceedings of the New Zealand Grassland Association 46: 41-46 (1985)

\title{
A MIXED CROP STOCK FARMLET ON A ROSTERED WATER SUPPLY
}

R. STOKER and C.G. JANSON

Winchmore Irrigation Research Station, MAF, Ashburton

Abstract

The on-farm water supply on the Mid Canterbury irrigation schemes of 230 litre/sec for one day per week for every 80 hectares of farm area has traditionally been considered capable or irrigating only about one half or two thirds of the total farm area. Many farmers have border dyked about this proportion of their farms leaving the remainder dryland.

In 1978 a farmlet with the whole area prepared for irrigation but still subject to the normal limitations of the rostered water supply was set up at Winchmore. Half of the area is in cash crop. Through a careful selection of crops and sowing dates each crop can be irrigated for maximum yield without exceeding the water allocation. On the remainder of the farmlet half the area is in grass clover pasture and half in lucerne. The water supply permits this to be irrigated at four weekly intervals or more frequently before and after the period of crop irrigation.

Crop production on the farmlet has only been average. For instance wheat and barely have generally yielded between 3.5 and 5 tonnes per hectare. Soil moisture monitoring suggests that limitations have not been imposed by the irrigation regime itself but by such factors as late sowing the crop or undersowing with pasture.

Over the three year stand life herbage production has averaged over $11000 \mathrm{~kg} / \mathrm{ha}$ with annual yield of lucerne exceeding that of grass/clover pasture in the first season ex crop. Stocking rates between 13 and 15 ewes/ha measured over the whole farm area or 26-30/ha on spring grazing area have been adopted with large variations in production.

With recent changes in the relative economics of sheep and cropping it has been decided to increase the emphasis on the crop aspect of the farmlet. The cropping area has been increased to twothirds. The farmlet is still run under the limitations of the rostered water supply but water may now be transferred from the herbage to crop at critical times. At the expense of small losses in herbage production crop yields will be increased substantially by eliminating such practices as late sowing dates and undersowing.

Keywords: Irrigation, roster, crop, stock.

\section{INTRODUCTION}

In the older Canterbury irrigation schemes such as the Ashburton-Lyndhurst, Mayfield-Hinds, and Valetta, water is allocated to each farm on the basis of a continuous flow of $0.4 \mathrm{~L} / \mathrm{sec} / \mathrm{ha}$. This contrasts with some of the more recent schemes such as the Glenavy-Morven which have a water duty of $0.7 \mathrm{~L} / \mathrm{sec} / \mathrm{ha}$. The lower water duty of the early schemes was decided on the basis that only part of each farm should be irrigated. The philosophy of the time is illustrated in two Christchurch Press articles of July 1946. One of these states:

"The area embraced by the (Ashburton-Lyndhurst) schemes is 64,000 acres, but sufficient water is available for only half that area, so that at the schemes maximum capacity farmers may be able to irrigate only half their farms - which should none the less be quite adequate as they would certainly require part of their land to be dry". 
The other article states:

"Farmers would be well advised to make haste slowly. They should start in a small way, and finance out of profits, and at the same time make sure they are able to handle the irrigated land. The propaganda put out earlier that irrigation was safe and sure and offered an immediate fortune is entirely groundless. Good will come of it, but only if we proceed slowly."

The extreme caution of the early days is understandable in that irrigation was a completely new management system for the farmers within the scheme areas. However, these attitudes caused an extremely slow development. As an example; over the first thirty years of operation the Ashburton-Lyndhurst scheme annual land preparation averaged only 365 hectares, resulting in about 40 percent of the gross area being prepared for irrigation. (Fitzgerald 1974). This was despite upward revisions of the land area that could be irrigated with the available water from the original "half" to "five-eighths" and then "two-thirds".

From the long term irrigated pasture (Rickard 1972) and crop (Stoker 1977) trials at Winchmore it became apparent in the early 1970's that even when strictly restricted to the water duty of $0.4 \mathrm{~L} / \mathrm{sec} / \mathrm{ha}$ it may be profitable to both the farmer and the nation to prepare 100 percent of each farm for irrigation. By changing from twothirds irrigation to full irrigation individual paddock production may be decreased slightly but total farm production is increased because of the absence of low producing dryland.

With this philosophy in mind it was decided to set up a fully irrigated farmlet run under the restriction of the Canterbury rostered water supply with no extra water. This farmlet was established at Winchmore in 1978 with the stated purpose of demonstrating and measuring the effective use of this water supply in a mixed crop/stock system. Effectiveness of the farmlet was measured both in terms of production and the soil moisture regime attained.

\section{Water Allocation}

The water duty of $0.4 \mathrm{~L} / \mathrm{sec} / \mathrm{ha}$ is supplied to the farmer as a flow of $230 \mathrm{U} / \mathrm{sec}$ for 24 hours per week for every 80 hectares of his land area. Often in the past farmers have had the luxury of extra water but this has become less available as greater areas have been developed and further restrictions placed on minimum river flows.

How effective can we irrigate with this rostered water supply? This depends very much on how well the system is engineered. With a well designed and constructed system irrigation rates of about $0.7-1.0$ halhr are possible on grass and about 0.4-0.7 ha/hr on crop. However, excessively long strips, poorly maintained sills and unfenced headraces can reduce these rates very considerably. If we consider a 240 hectare farm with its whole area prepared for irrigation the return period can be calculated (Table 1). In other words, an all-grass farmer with his whole farm prepared for irrigation can expect to water each hectare every four weeks, an all-crop farmer would take six weeks and a mixed pastoral/cropping farm would be somewhere in between. With these return periods management comes under pressure particularly with crops. Many farmers have opted out of the problem by leaving part of the farm non-irrigated. In fact on the Canterbury schemes very few farms are prepared for total irrigation.

Table 1: IRRIGATION RETURN PERIODS FOR FULLY IRRIGATED FARM

\begin{tabular}{|c|c|c|}
\hline & Pastoral Farm & Croooina Farm \\
\hline Farm Area & 240 ha & 240 ha \\
\hline Water Allocation & 72 hrslweek & 72 hrslweek \\
\hline Irrigation Rate & $0.85 \mathrm{ha} / \mathrm{hr}$ or $60 \mathrm{ha} /$ week & $0.55 \mathrm{ha} / \mathrm{hr}$ or 40 ha/week \\
\hline Return Period & $240160=4$ weeks & $240 / 40=6$ weeks \\
\hline
\end{tabular}


Water supply to the Winchmore farmlet is based on the calculated return periods of four weeks on pasture or lucerne and six weeks on crop rather than on a particular time of water flow. This procedure does not allow for the changing watering rate as the season proceeds but it does avoid dependence on the particular efficiency of the farmlet irrigation system which is probably above average. An additional rule of the farmlet is that water cannot be transferred between the areas in crop and pasture during the crop watering period.

\section{THE FARMLET - PHASE 1}

The farmlet consists of six main areas - three in crop and three in pasturellucerne. The watering rules permit the grazing area to be watered every two weeks early and late in the season, when the crops do not require water. While the crops are being watered the grazing area can only be watered every four weeks. The three main grazing areas in the rotation are each split into lucerne and grass/clover pasture, in order to compare the two in a short term irrigated situation. The watering rules permit one of the three crop areas to be irrigated every two weeks. ( 6 week return period for 3 crops). Small non-irrigated control plots were included on the farmlet in order to measure irrigation responses.

From the 1981182 season onwards crops were direct drilled. The original crop rotation includes linseed bu! with the demise o f this industry the rotation was changed from the 1982183 season (Table 2). It should be noted that both these rotations contain a proportion of crops with an early and late water requirement to spread the irrigation period to over at least ten weeks. The crop irrigation package complies with the water allocation rules and the moisture regime experienced by individual crops is likely to be close to optimum based on experience of previous crop irrigation trials.

Table 2: CROP ROTATION

\begin{tabular}{|c|c|c|}
\hline Crod & Sowina Date & Irrigation \\
\hline \multicolumn{3}{|l|}{ a) $1978179-81 / 82$} \\
\hline Linseed (Reedwood) & Early November & Late Dec, Late Jan \\
\hline Wheat (Kopara, Rongotea) & Late May & Mid Nov \\
\hline Barley (Zephyr) & Late September & Late Nov, Mid Dec, Mid Jan \\
\hline $\begin{array}{l}3 \text { years lucerne or grass/ } \\
\text { clover pasture }\end{array}$ & with barley & $14 / 28$ days \\
\hline \multicolumn{3}{|l|}{ b) $1982163-83184$} \\
\hline Barley (Magnum) & Early November & Late Dec, Late Jan, Early Feb \\
\hline Peas (Whero) & Mid May & Late Oct, Mid Nov \\
\hline Wheat (Oroua) & Late September & Late Nov, Mid Dec, Mid Jan \\
\hline $\begin{array}{l}3 \text { years lucerne or grassl } \\
\text { clover pasture }\end{array}$ & with wheat & $14 / 28$ davs \\
\hline
\end{tabular}

\section{Crop Performance}

The farmlet commenced in the $1978 / 79$ season with the crops being sown on an area with a previous history of a long term wheat trial infected with take-all. Consequently yields were low in the first two seasons although the water supply proved adequate to maintain soil moisture near optimum in all three crops. Yields improved in later seasons (Table 3).

The crop yields achieved were lower than expected but this was due to factors other than the irrigation regime imposed. In general the water supply proved sufficient to maintain soil moisture at levels known to be adequate to produce near 
maximum yields. Some shuffling of irrigations occurred however $\boldsymbol{-}$ albeit while remaining within the watering rules of the farmlet. For instance in the 1978179 to 1981182 rotation the third irrigation was not applied to the barley. By mid-January the barley was too mature to benefit from this irrigation and the water was applied to the linseed in dry seasons.

The factors that have limited crop production have mainly revolved around the late sowing dates of spring wheat and barley which were needed to fit in with the irrigation schedule. In addition the practice of undersowing the pasture and lucerne has required lower sowing rates of the cover crop and has restricted application of nitrogen.

Table 3: CROP YIELDS (KG/HA AT 12\% MOISTURE)

\begin{tabular}{llrll}
\hline Year & Treatment & Linseed & Wheat & Barlev \\
\hline $1980 / 81$ & Non irrigated & $570 \mathrm{~b}^{1}$ & $2970 \mathrm{~b}$ & $4830 \mathrm{a}$ \\
& Irrigated & $2800 \mathrm{a}$ & $5130 \mathrm{a}$ & $5160 \mathrm{a}$ \\
1981182 & Non irrigated & $430 \mathrm{~b}$ & $3050 \mathrm{a}$ & $2550 \mathrm{~b}$ \\
& Irrigated & $2680 \mathrm{a}$ & $3320 \mathrm{a}$ & $3550 \mathrm{a}$ \\
& & Peas & Wheat & Barlev \\
\hline \multirow{2}{*}{1982183} & Non irrigated & $1860 \mathrm{~b}$ & $2650 \mathrm{~b}$ & $2970 \mathrm{~b}$ \\
& Irrigated & $4530 \mathrm{a}$ & $3760 \mathrm{a}$ & $4520 \mathrm{a}$ \\
& Non irrigated & $1760 \mathrm{~b}$ & $3100 \mathrm{~b}$ & $5800 \mathrm{a}$ \\
& Irrigated & $2350 \mathrm{a}$ & $4200 \mathrm{a}$ & $6100 \mathrm{a}$ \\
\hline
\end{tabular}

1 Values followed by different letters are significantly different at $P<0.05$ level

Table 4: SOIL MOISTURE (S.M.) AND IRRIGATION FREQUENCY ON GRAZING AREA

\begin{tabular}{lrrrr}
\hline & 1990181 & 1981192 & $\mathbf{1 9 8 2 / 8 3}$ & 1993184 \\
\hline Mean number of irrigations & 6 & 5 & 7 & 5 \\
$\%$ of irrigations above 15\% s.m. & 79 & 56 & 82 & 60 \\
$\%$ of irrigations above 10\% s.m. & 100 & 100 & 100 & 100 \\
\hline
\end{tabular}

\section{Herbage and Stock Performance}

The number of irrigations applied to the pasture and lucerne paddocks and the soil moisture status of these paddocks prior to irrigation is given in Table 4.

The majority of irrigations were applied when soil moisture was above 15 percent. The 15 percent treatment on a long term pasture irrigation trial at Winchmore has yielded over 90 percent of that obtained with unlimited water. (Rickard 1981). This is reflected in the relatively high yields of herbage produced (Table 5).

Table 5: MEAN ANNUAL HERBAGE PRODUCTION 79/80-81/82 (KG/HA DM)

\begin{tabular}{lccc}
\hline Years ex CroD & $\mathbf{1}$ & $\mathbf{2}$ & $\mathbf{3}$ \\
\hline Lucerne & 11460 & 13260 & 10260 \\
Grass/clover & 9490 & 12730 & 10540 \\
\hline
\end{tabular}


The stocking rate was adjusted a number of times in an attempt to find the best compromise between stocking rate and acceptable animal performance. The initial stocking rate of 13 ewes/ha (1980181) gave a high stock performance with a surplus of herbage. In 1981 this was increased to 15 ewes/ha. This higher stocking rate over two years gave unacceptable stock performance and a further adjustment to 14 ewes/ha was made for the 1983184 season. Stock performance is summarized in Table 6.

\section{Table 6: STOCK PERFORMANCE 1980/81-1983/84}

\begin{tabular}{|c|c|c|c|c|}
\hline & 80181 & $81 / 82$ & $82 / 83$ & 83184 \\
\hline Lambs sold/ewes mated $(\%)$ & 142 & 118 & 103 & 101 \\
\hline Lamb carcase weight sold $(\mathrm{kg} / \mathrm{ha})$ & 237 & 218 & 197 & 187 \\
\hline Average carcase weight $(\mathrm{kg})$ & 12.7 & 12.3 & 12.7 & 13.6 \\
\hline \multicolumn{5}{|l|}{ Stocking Rate (ewe/ha) } \\
\hline Over shole farmlet & 13 & 15 & 15 & 14 \\
\hline Over spring/summer grazing area & 23.8 & 27.4 & 27.4 & 25.6 \\
\hline Ewe replacements $=$ & $17.5 \%$ & vorths) & & \\
\hline
\end{tabular}

\section{THE FARMLET - PHASE 2}

This farmlet has shown that it is practical to irrigate the whole of a mixed crop/stock property with a water duty of only $0.4 \mathrm{~L} / \mathrm{sec} / \mathrm{ha}$. Soil moisture levels recorded under the watering rules of the farmlet have been adequate for high production levels of both crop and stock. Actual production levels achieved have been limited on the cropping side by the restrictions on sowing date needed to fit in with the irrigation roster, and also by the need to establish a good undersown pasture which necessitates limitations on sowing rate and nitrogen input. Despite the rather average cropping performance the farmlet has proved valuable for its stated aim of demonstrating and measuring the effective use of a limited water supply in a mixed crop/stock system.

An original rule of the farmlet was that water should not be transferred between the crop and herbage areas during the period of crop irrigation. The rationale for this was that at the time the farmlet was planned, stock and crop returns were very similar and the aim was to go for high returns from each component. This balance of priorities between the crop and stock parts of the farmlet could be economically justified when the unit began in 1978. However, since that time the prices, yield potential and market prospects for several of our major crops have improved and reevaluation of this farmlet has been undertaken.

Financial analyses based on the gross margin approach established that by making three simple but rather basic changes to the management of the unit net profitability could be improved by about $\$ 200$ per hectare. The three changes were (1) advancing sowing date of the cereals, (2) increasing $N$ fertiliser usage and stopping the undersowing of pastures and (3) altering the irrigation allocation policy to one in which the crops have priority for water over the non-crop part of the unit during November and December. These changes, while increasing the predicted crop yields also reduced animal production from the farmlet but the overall effect, an increase of $\$ 200 /$ ha in net profit, clearly shows the policy direction in which this unit should move. During phase 2 of this farmlet it has been decided to increase the cropping intensity of the unit from $50 \%$ to $66 \%$ of the area in crop over the spring/summer period.

As a result of these policy changes the following choice and sequence of crops will apply from the 1984185 season. 


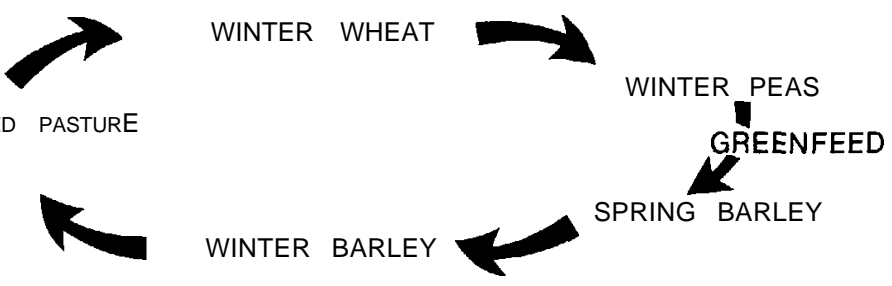

The policy of these crops will be to maximise net profit by striving for high yields and applying inputs liberally right up to the economic threshold. This will mean

(a) sowing early (winter wheat and winter barley $\rightarrow$ early May; winter peas - mid May; spring barley - August/September)

(b) using $\mathrm{N}$ fertiliser liberally

(c) monitoring insects and disease closely and controlling them promptly

(d) always giving the crops priority for water over the pasture whenever a crop irrigation response is likely

(e) promoting maximum herbage yields of the greenfeeds by establishing them as quickly as possible after crop harvest.

The unit will continue to demonstrate the use of a $0.4 \mathrm{~L} / \mathrm{sec} / \mathrm{ha}$ water duty for 100 percent irrigation. The changes will necessitate a small reduction in stock'numbers on the unit and possibly some changes in the stock policy. However, the overall profitability of the unit will be increased considerably through the improved crop programme.

\section{ACKNOWLEDGEMENTS}

The authors gratefully acknowledge the assistance received from Ken Carter, Mike Daly, Trevor Knight, and the late Gavin Scott with the planning, field work and recording associated with this farmlet.

\section{REFERENCES}

Fitzgerald, P.D. 1974. The effect of climate on water use in Canterbury irrigation schemes. Winchmore Irrigation Research Station Technical Report No. 8.

Rickard, D.S. 1972. Investigations into the response of pasture to irrigation, 1950151 to 195617. Winchmore Irrigation Research Station Technical Report No. 5.

$$
\text { 1981. Frequency of irrigation on pasture. Winchmore Irrigation }
$$
Research Station. Guide; section 3/2.

Stoker, R. 1977. Irrigation of annual legumes. Proceeding of soil and plant water symposium. Palmerston North 1976. 